\title{
Social Network Approach for Sharing Knowledge: How Can the Structure and Characteristics of Social Networks Support for Sharing Knowledge?
}

\author{
지식 공유에 대한 소셜 네트워크 접근법 : \\ 어떻게 소셜 네트워크의 구조와 특징이 지식 공유를 지원하는가?
}

Jeongsoo Lee*

\begin{abstract}
The knowledge sharing in a knowledge management process is much affecting generation and distribution of knowledge. Especially, the knowledge distribution is being revitalized with the center of social media service like twitter and library service 2.0 in the knowledge-based IT (Information Technology) environment. The present research analyzed the structure and characteristics of a social network inside an organization that is growing like an organism through self-organization through tools for SNA (Social Network Analysis) and multiple regression analysis of independent variables such as 1) a relationship between social network's structure and knowledge sharing, 2) a relationship between structural holes and knowledge sharing influence of centrality, 3) a relationship between individual ability and knowledge sharing of information technology and work recognition.
\end{abstract}

\section{초 록}

지식관리 프로세스에서 지식공유는 지식의 생성 및 분배에 많은 영향을 주고 있다. 특히, 지식기반 정보기술 환경이 트위터와 같은 소셜미디어 정보서비스 등의 라이브러리 2.0 서비스를 중심으로 지식유통이 활성화되고 있다. 지식공유의 영향 요소에 사회연결망 구조 및 특징에 대한 네트워크의 관계 요소가 조직의 지식공유 활성화를 위한 중요한 요인으로 인식되고 있다. 본 연구는 자기조직화를 통해 유기체와 같이 성장하고 있는 조직 내부의 사회연결망의 구조 및 특성을 사회연결망 분석도구와 다중회귀분석을 통해 1) 사회연결망의 연결구조와 지식공유와의 관계, 2) 구조적 공백과 중심성의 지식공유 영향도, 3) 개인적인 능력, 정보기술 및 업무 인식과 지식공유 관계를 분석하였다.

Keywords: knowlege network, knowledge sharing, SNA (social network analysis), strong-weak tie, structural holes, network characteristics, digital library

지식네트워크, 지식공유, 사회연결망분석 (SNA), 강한연결 구조, 구조적 공백, 네트워크 특징, 디지털도서관

* Fulltime Lecturer. Department of Library and Information Science, Daelim University College (leejeongsoo@daelim.ac.kr)

- Received : 14 May 2010 - Revised : 4 June 2010 - Accepted : 14 June 2010

- Journal of the Korean Society for Information Management, 27(2): 61-74, 2010.

[DOI:10.3743/KOSIM.2010.27.2.061] 


\section{Introduction}

Knowledge is the foundation of Innovation (Drucker 1993). and Knowledge is one of the most important elements of core competences (Khamseh and Jolly 2008). The knowledge sharing and delivery field is most important in a process converting tacit knowledge into formal knowledge among knowledge processes of the knowledge management field of production, sharing, delivery and utilization (Kim 1999; Nonaka and Taketuchi 1995).

Integration process that one willingly exchanges his knowledge with other members of the organization based on social, business, technological networks. Dynamic phenomenon to be made buy interaction between members of the organization (O'Dell and Grayson 1998), and can be defined the important interaction process which become a base for getting competition predominance of the organization (Ciborra and Patriota 1998; Bock and Kim 2002).

Recently, the social network service is being raised as a killer service of a web environment, and is being recognized as the most important part of web 2.0. The interoperability for sharing, cooperation and integration, which are a key of web evolution is forming a more and more complex network. Also, the PKM (Personalized Knowledge Management) is being revitalized as it enters an ubiquitous environment oriented to mobile devices. The appearance of various personalized devices centered to a smart phone and tablet PCs, etc. through a wireless network would achieve much more mutual cooperative knowledge distribution. The opening of a contents network based on explosive information, high performance, large capacity of devices and open platform is recognized as the core that the efficient knowledge management of an information technology environment can occupy the superiority in a competitive environment.

The knowledge sharing in a process of this knowledge management has much influence on generation and distribution of knowledge due to utilization expansion of knowledge. The researches on properties of knowledge, individual and organizations of knowledge, and properties of information technology were much carried out for efficient knowledge sharing. But as shown in the present information technology environment, the knowledge is evolved in an environment that is cooperated and mutually shared through a network. Therefore, the present research utilizes the SNA (Social Network Analysis) techniques by classifying knowledge network data of various data through analysis on network structure and properties of knowledge, and analyzes if the structure and properties of a network have any influence on knowledge sharing of knowledge management. Also, this research aims to utilize indexes for knowledge sharing by analyzing properties of social network structure of knowledge management.

The objectives of the study are summarized as follows: Firstly, index development and analysis of structure and characteristics the social network for knowledge sharing, which are its cores. And secondly, analysis of influence factors of knowledge sharing in order to build and use the effective knowledge network of the organization. 


\section{Background}

\subsection{Knowledge Sharing}

The most important element is knowledge management for obtaining competitiveness of an organization as well as securing individual competitiveness, and knowledge sharing in knowledge process can be said to be significant part connected most closely with its creation, expansion and application. Like knowledge creation, knowledge sharing is the most basic process for securing competition predominance of the organization. Accordingly, various discussions on it are being made, and diverse definitions are being given by many scholars.

The concepts of knowledge sharing presented in the existing literature can be divided into a viewpoint to understand it as interaction between members in the organization, a viewpoint to understand it as an approach process to knowledge, and a viewpoint to stress Knowledge transfer and exchange etc.

Pointing out that the notions of knowledge sharing and knowledge transfer are used without clear distinction, Allee (1997) argued that the reason why this happens is because of researchers' unclear recognition of the viewpoint to see knowledge. In other words, if you recognize knowledge as an object which can be transferred, the concept of knowledge transfer will be appropriate, and if you recognize it as a process which is difficult to transfer, that of knowledge sharing will be suitable. Allee is actually explaining knowledge sharing is used in some more comprehensive sense to emphasize social interactions compared to knowledge transfer.

Terms such as knowledge sharing, transfer, transmission, diffusion, distribution and so forth are similar concepts and used as the same meaning, but can be defined at different levels and types depending on researchers' research fields, characteristics and approaches. However, to enhance values and goals of organization and performance and by individuals or organizations' using knowledge created by other individuals or organizations is generally agreed between scholars.

If generalizing precedent studies on knowledge sharing, it can be defined as the interaction process that one willingly exchanges his knowledge with other members of the organization based on social, technological networks. In this respect, knowledge sharing can be understood as a dynamic phenomenon to be made buy interactions between members of the organization, and can be defined the important interaction process which becomes a base for getting competition predominance of the organization.

In order to examine various influence factors of knowledge sharing, I investigated research results by literature and a number of scholars. For influence factors, I examined them by dividing into Knowledge Characteristics, Individual, Organizational, Inter-organizational, International, and University-Industry, it was found that researches in Organizational were made most.

The impact factor of knowledge sharing was researched by numerous scholars. Wiig (2000), Simonin (1999), Colman (1999), Davenport (1998), Ruggles (1998), Deckman (1998), Roos and Roos (1997) But 
as the properties on a knowledge network becoming a basis of knowledge sharing weren't added to a category of an impact factor of important knowledge, the present research aims to analyze the impact factor on properties of a knowledge network.

\subsection{Social Network Analysis and Applications}

Social Network is a term which began to be used by J.A. Barnes in 1953, and is an important research methodology used in the filed of social science for a long time. It is to explain social effects arising from of behavior patterns and relationships of human relations and is based on the graph theory like general network theories.

This social network can be interpreted as a mechanism to evolve into the information ecosystem by relationships generated through work to collaborate with others and share information with them or through data produced based on this. Social Network Analysis means a series of processes to reach Information and Knowledge processing by measuring relations between objects such as society members and contents etc and mapping associated information. This social network becomes a foundation of analysis of the information network as a method to efficiently apply knowledge scattered in the organization of knowledge and economy-based society and create new knowledge (David J. Skyrme 2000). Therefore, the organization can secure flexibility of intellectual capital sharing and creation trough building and using the knowledge network.
The social network analysis for the knowledge network analysis has been developed by numerous theories. Two approaches of network means approaching through forms connected by interactions between society members. Firstly, there are Strong tie and networks (Burt 2000; Podolny and Baron 1997). Granovetter (1973) argues that strong tie is decided by time, emotional intensity, familiarity, and mutual services. This network plays a role of increasing trust and strengthening norms (Coleman 1990; Krackhardt 1992). Secondly, there is Weak tie. Network becomes a passage for information and knowledge to be transferred. Information and knowledge necessary for tasks are conveyed by official or informal network. The strong point of weak time is that it takes less time and energy to keep the network. Additionally, it plays a role of a bridge to connect networks or groups etc. Through the passage of communication through network, information and resources get to be transferred, which are closely connected with organizational and individual performances. Burt (2001) called the efficient tie concept of this weak tie as Structural Holes and defined it as a position to connect individuals who are not connected in the network.

The present study aims to examine how the features of the strong tie and the weak tie, and the characteristics of social capital as structural holes of tie-structure affect knowledge sharing.

The structure and characteristics of social network are analyzed through its tools. The tools of social network apply the model of the mathematical social network theory to structure and relations of nods of knowledge. Analysis tools to identify, express, 
analyze, take statistics, visualize and simulate various types of relational and non-relational input data include UCINET, Pajek, Netminer3 and so forth, and the present study used Netminer3.

\section{Methods and Research Model}

\subsection{Research Question}

$<$ Table $1>$ describe the Research question of tie relation, structural holes and centrality, individual capacities. Firstly, how does the organization's social network tie relation affect knowledge sharing? And then, how do structural holes as nature of its social network affect knowledge sharing? Lastly, how do individual capacities affect knowledge sharing? And how do information technology and use of task awareness affect knowledge sharing?

\subsection{Procedures \& Research Methodology}

$<$ Figure $1>$ shows the entire procedures of the study. They are processes to make social network analysis and statistics by collecting data after developing research models and setting up analysis index.

The entire models of research are as follows $<$ Figure $2>$.

Hypotheses of them are composed of three. Hypo-

\section{〈Table 1〉 Research Question}

\begin{tabular}{c|l}
\hline Q1 & How does the organization's social network tie relation affect knowledge sharing? \\
\hline Q2 & How do structual holes as nature of its social network affect knowledge sharing? \\
\hline Q3 & $\begin{array}{l}\text { How do individual capacities affect knowledge sharing? } \\
\text { How do information technology and use of task awareness affect knowledge sharing? }\end{array}$ \\
\hline
\end{tabular}

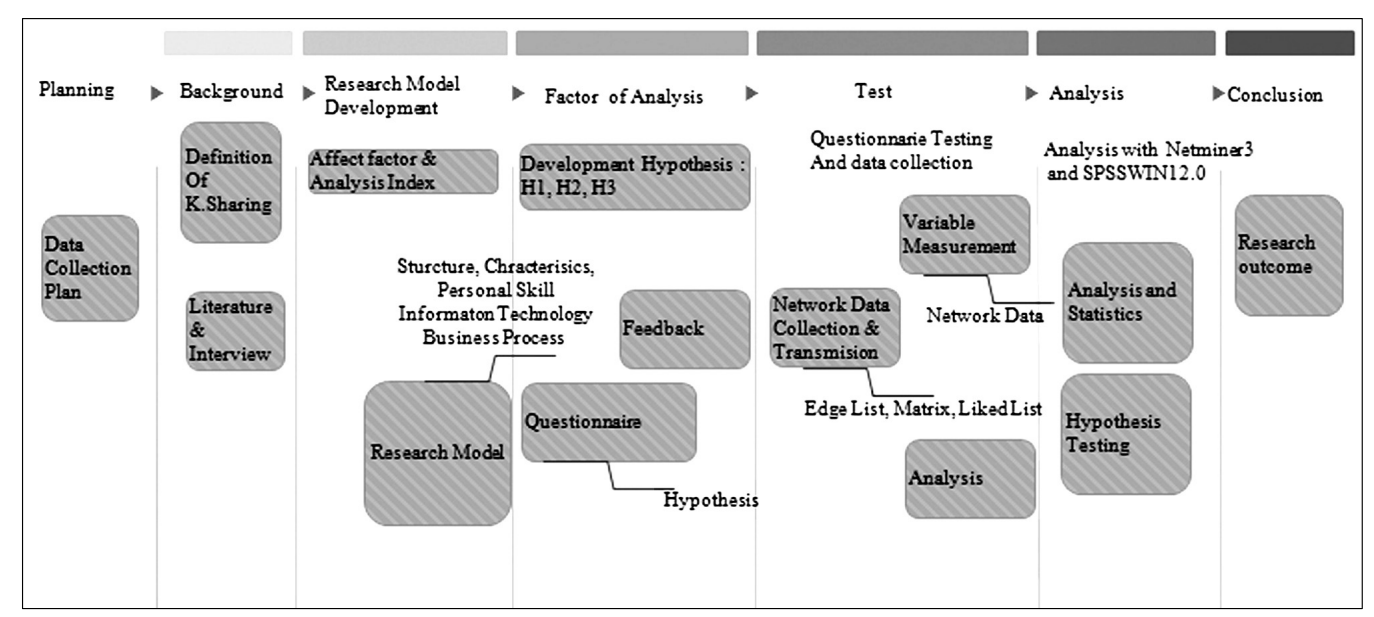

〈Figure 1〉 Procedure 


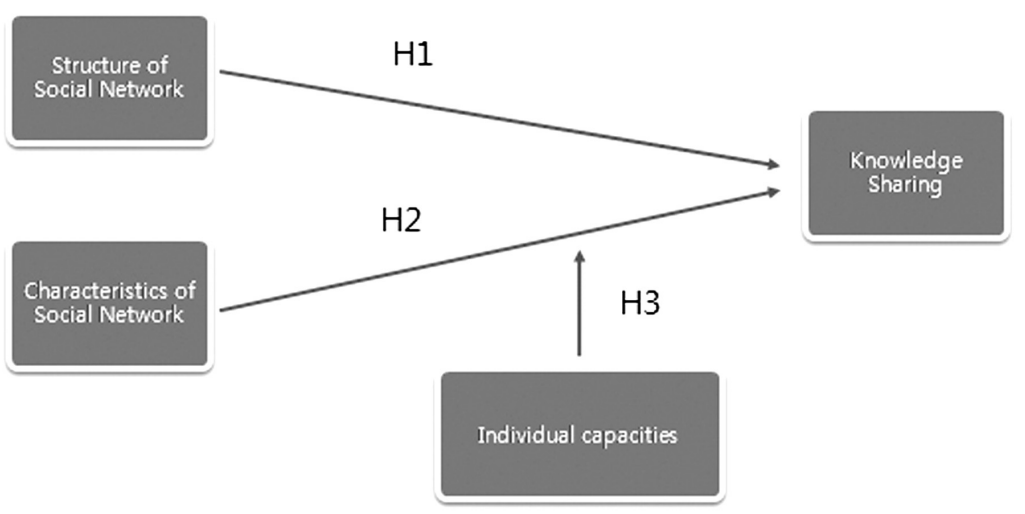

〈Figure 2〉 Research Model

thesis 1 refers to relationships between tie structure of social network and knowledge sharing, and hypothesis 2 refers to relationships between structural holes and center of social network and knowledge sharing. And finally, hypothesis 3 was formed as relationships between individual capacities, information technology, task recognition, and knowledge sharing.
$<$ Figrue 3> describes operationalization of the variables. $<$ Figure $3>$ shows that the independent variables of a social network is simulated with the center of an analysis factor of a social network by applying Netminer3, which is a SNA analysis tool. The measured content is analyzed after being divided into CONNECTION, CENTRALITY and COHESION.

\section{$\langle$ Table 2〉 Hypotheses}

\begin{tabular}{c|l}
\hline H1 & Relationships between tie structure of social network and knowledge sharing. \\
\hline H1-1 & The degree of social network's structure is positiely associated with the Knowledge sharing. \\
\hline H1-2 & The strong tie of social network in truth is positivly associated with the knowledge sharing. \\
\hline H1-3 & The weak tie of social network in business group is positivly associated with the knowledge sharing. \\
\hline H1-4 & The weak tie of social network in IT group is positivly associated with the knowledge sharing. \\
\hline H2 & Relationships between structural holes and centrality of social network and knowledge sharing. \\
\hline H2-1 & $\begin{array}{l}\text { The low level of constraints and redundancy in structural holes is positivly associated with the knowledge } \\
\text { sharing. }\end{array}$ \\
\hline H2-2 & $\begin{array}{l}\text { The degree centrality, closeness centrality, betweenness centrality is positivly associated with the } \\
\text { knowledge sharing. }\end{array}$ \\
\hline H3 & $\begin{array}{l}\text { Relationships between individual capacities, information technology, task recognition, and knowledge } \\
\text { sharing. }\end{array}$ \\
\hline H3-1 & The degree of personal innovation skill is positively associated with the knowledge sharing. \\
\hline H3-2 & The degree of authority is positively associated with the knowledge sharing. \\
\hline H3-3 & The degree of awareness in business is positively associated with the knowledge sharing. \\
\hline H3-4 & The degree of awareness in It is positively associated with the knowledge sharing. \\
\hline
\end{tabular}


The present research was analyzed with Network Density (Scott 1992; Burt 1992) of tie for analysis of a social network, and with Degee Centrality, Closeness Centrality, and Betweenness Centrality (Freedman 1977), and Redundancy, Constraints (Burt 1992).

$<$ Figure $4>$ shows that the measured SNA analysis data were systematized as independent variables to be suitable for a purpose of the present research.

The measured social network's data is divided into Structure of social network, Characteristics of social network, and Individual Capacities.

$<$ Figure 5> shows a measurement of knowledge sharing which is a dependent variable.

$<$ table $3>$ shows that this research describe the

\begin{tabular}{|l|l|}
\hline $\begin{array}{l}\text { SNA } \\
\text { Measurement }\end{array}$ & \multicolumn{1}{c|}{ content } \\
\hline CONNECTION & $\begin{array}{l}\text { Degree, Density, Inclusiveness, Density, Structure hole, Path } \\
\text { distance, Geodesic distance, Redundancy }\end{array}$ \\
\hline CENTRALTY & $\begin{array}{l}\text { Degree centrality, closeness centrality, Between centrality, } \\
\text { centralization }\end{array}$ \\
\hline COHESION & Component, Clique, Structural equivalence, \\
\hline
\end{tabular}

〈Figure 3〉 SNA Measurement

\begin{tabular}{|c|c|c|}
\hline $\begin{array}{c}\text { Independent } \\
\text { Control } \\
\text { Variable }\end{array}$ & method & content \\
\hline & Structure of social network & Awareness, truth, Business type \\
\hline & Characteristics of social network & Structure holes, Centrality \\
\hline & Individual Capacities & Awareness of personal skill, $\Pi$, Business \\
\hline
\end{tabular}

〈Figure 4〉Independent Control Variable

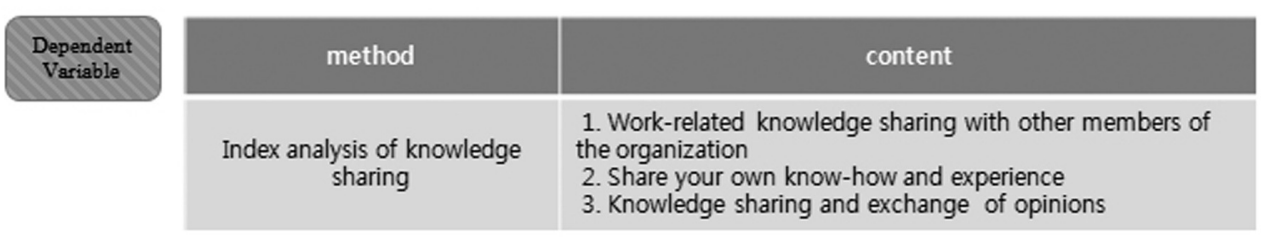

〈Figure 5〉 Dependent Variable 
〈Table 3〉 Characteristics of Participants and Anaysis

\begin{tabular}{|c|c|}
\hline Participants & $\begin{array}{l}\text { - How to Experiment : A Library in South Korea } \\
\text { - Participants : } 53 \text { Librarian } \\
\text { - Two Group : Business, Information Technology Type } \\
\text { - Pre-Research Duration : } 1 \text { month }\end{array}$ \\
\hline $\begin{array}{c}\text { Data } \\
\text { Collection }\end{array}$ & $\begin{array}{l}\text { - SNA Network Data Structure } \\
\text { Main Nodeset: People (Node=53) } \\
\text { 1-Mode Network Data : Know, Truth } \\
\text { Sub Nodeset: Skill, Technology, Business } \\
\text { 2-Mode Network Data }\end{array}$ \\
\hline Analysis & $\begin{array}{l}\text { - SNA : Network data Anaysis, Netminer3 } \\
\text { Density (Wasserman \& Faust 1994; Freeman 1979) } \\
\text { Contraint (Burt 1992) } \\
\text { Centrality (Freeman 1979; Vladimir 2002) } \\
\text { - SPSSWin 12.0: Descriptive, Correlation, Regression } \\
\text { p }<.05^{*}, \quad \text { p }<.01^{* *}, \quad \text { p }<.001^{* * *}\end{array}$ \\
\hline
\end{tabular}

participant and duration of my research. In total, 53 participants voluntarily joined the research. I divided the participants into two groups- the "Business group" and the "IT group". The research has lasted for the past one month.

\section{Research Outcome}

I processed the as network data collecting survey data, and conducted an analysis of SNA and descriptive statistics of SPSSWin 12.0, correlation statistics, and regression analysis. The descriptive statistics and analysis are as follows $<$ Figure $6>$.

The ratio of men and women was respectively $36 \%$ and $64 \%$ among surveys, and their business type was respectively distributed as $51 \%$ and $49 \%$. Especially, the ratio of a staff was $79 \%$ and was highest, and the ratio of a manager was surveyed as $15 \%$ in the business level.

Reliability and feasibility were analyzed by Cronbach's analysis, correlation analysis was made by variable by Pearson's Correlation Analysis, and they selected and rejected analyzing hypotheses through multiple regression analysis.

The reliability analysis results on component variables of concepts consisting of Structure of Social Network, Characteristic of Social Network, Individual Capacities is the same as $\langle$ Figure $7>$ in the present research. The Degree of awareness, Degree of truth, degree of Business group and Degree of IT group were respectively analyzed as $.54, .65, .57$, and .54 . The Constraints and redundancy of structural holes, Degree Centrality, Closeness Centrality and Betweenness Centrality were respectively analyzed as .64, .62 , .64, and .06. Lastly, the Degree of Personal skill of Individual Capacities, Degree of Authority, Degree of awareness in Business and Degree of 


\begin{tabular}{|c|c|c|c|}
\hline Item & type & Count & $\%$ \\
\hline \multirow{2}{*}{ Sex } & Male & 19 & $36 \%$ \\
\hline & Female & 34 & $64 \%$ \\
\hline \multirow{2}{*}{ Business Type } & Business group & 27 & $51 \%$ \\
\hline & Information Technology group & 26 & $49 \%$ \\
\hline \multirow{4}{*}{ Level } & Staff & 42 & $79 \%$ \\
\hline & Researcher & 2 & $4 \%$ \\
\hline & Manager & 8 & $15 \%$ \\
\hline & Consultant & 1 & $2 \%$ \\
\hline
\end{tabular}

$\langle$ Figure 6〉 Descriptive statistics $(N=53)$

\begin{tabular}{|c|l|c|}
\hline \multicolumn{1}{|c|}{ Item } & \multicolumn{1}{|c|}{ variable } & Cronbach's $\alpha$ \\
\hline \multirow{2}{*}{ Structure of social network } & Degree of awareness & .54 \\
\hline & Degree of truth & .65 \\
\hline \multirow{2}{*}{ Characteristics of social network } & Degree of Business group & .57 \\
\hline & Degree of I group & .54 \\
\hline & Constraints and redundancy of structural & .64 \\
\hline & holes & .62 \\
\hline & Closeness Centrality & .64 \\
\hline & Betweenness Centrality & .63 \\
\hline & Degree of Personal skill & .56 \\
\hline & Degree of Authority & .64 \\
\hline
\end{tabular}

〈Figure 7〉 Reliability

awareness in IT respectively appeared as $.56, .64$, .73 and .72 .

The internal recognition of knowledge sharing, which is a dependent variable, appeared as 0.62 , so it appeared that there is no irrationality in reliability measurement.

The correlation analysis result between composition variables of social network's structural characteristics of the present research is the same as in $<$ Figure $8>$. As a result of examining the correlation among 


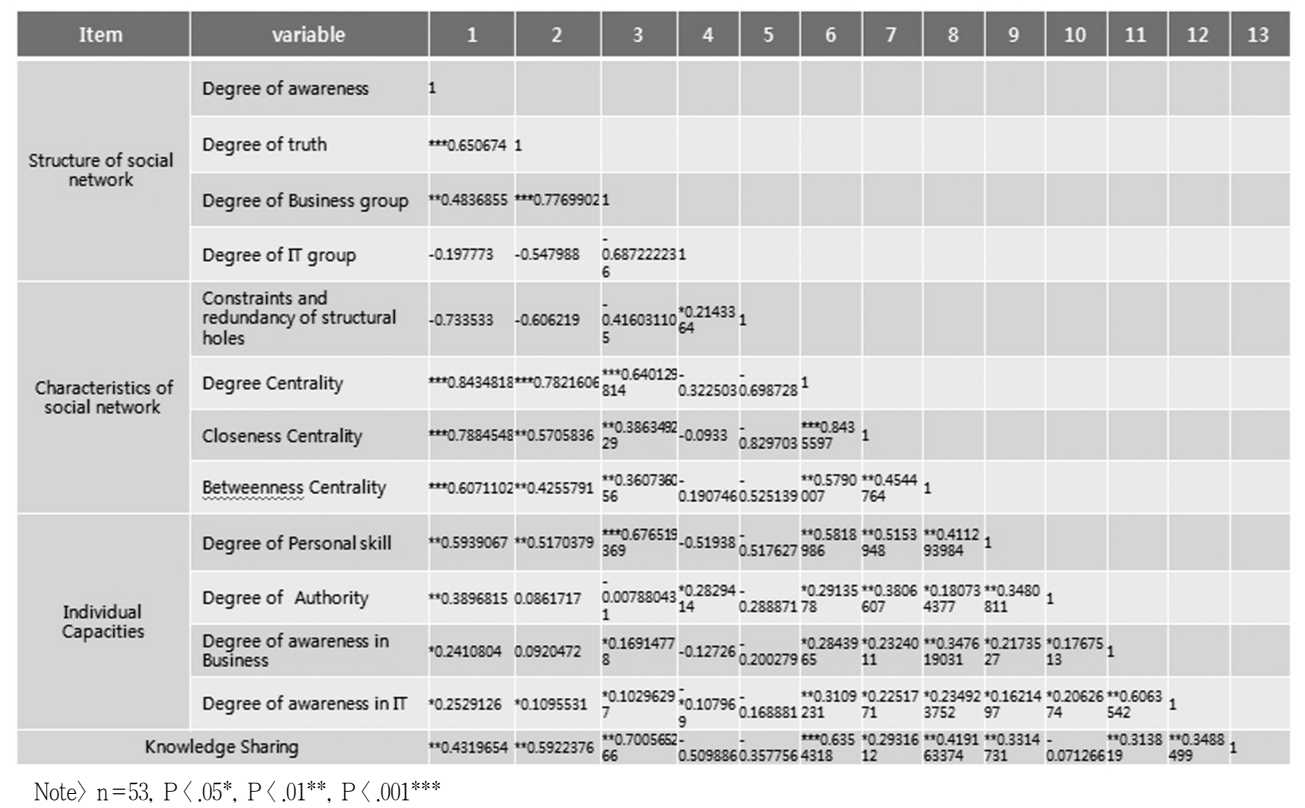

〈Figure 8〉 Pearson's Correlation Anaysis

independent variables, factors of Structure of Social Network, Characteristic of Social Network, Individual Capacities and a knowledge sharing factor of dependent variables, it appeared that the correlation of between the Degree awareness and Degree Centrality, between Closeness of Centrality and Degree Centrality, between Degree Centrality and Degree of truth, and between Degree of Business group and Degree of truth respectively shows $r=.843, r=.843$, $r=.782$ and $r=.0 .77$, so it showed a significant positive correlation.

The multiple regression analysis of 12 independent variables set for hypothesis verification of the present research to examine what variables have influence on knowledge sharing, and the result is the same as shown in the following $<$ Figure $9>$.

As shown in the result of $<$ Figure $9>$, because the total coefficient of determination $\left(\mathrm{R}^{2}\right)$ appeared as .80241 (Adj- $\left.\mathrm{R}^{2}=.74314\right)$, it was analyzed that the regression model is valuable $(\mathrm{F}=13.537, \mathrm{P}<.001)$.

As a result of multiple regression analysis, it appeared that the Degree of truth $(\mathrm{P}<.001)$ and Degree of Business group $(\mathrm{P}>.001)$ of Structure of Social Network have a significant positive influence. It was analyzed that the Constraint and redundancy of structural holes $(\mathrm{P}<.001)$, Degree Centrality $(\mathrm{P}<.001)$, Closeness Centrality $(\mathrm{P}<.001)$, Individual Capacities of Characteristics of Social Network showed that the Degree of Personal skill $(\mathrm{P}<.001)$ has a significant causal relationship with an independent variable of knowledge sharing.

It appeared that the relative influence of Characteristics of Social Network among three elements of independent variables is big. 


\begin{tabular}{|c|c|c|c|c|c|c|c|}
\hline Item & variable & $\begin{array}{l}\text { dependent } \\
\text { variable }\end{array}$ & $\begin{array}{c}\text { R2/ } \\
\text { Adj-R2 }\end{array}$ & $\mathbf{F}$ & $\mathrm{t}$ & P-value & $\begin{array}{l}\text { Select/ } \\
\text { Reject }\end{array}$ \\
\hline \multirow{4}{*}{$\begin{array}{l}\text { Structure of } \\
\text { social } \\
\text { network }\end{array}$} & Degree of awareness & \multirow{12}{*}{$\begin{array}{l}\text { Knowledge } \\
\text { Sharing }\end{array}$} & \multirow{12}{*}{$\begin{array}{c}0.8024178765 \\
22483 \\
0.7431432394 \\
79228\end{array}$} & \multirow{12}{*}{$\begin{array}{c}13.537288738 \\
4688 \\
1.5422308518 \\
5816 \mathrm{E}-10\end{array}$} & -0.374753 & 0.709823944 & $\mathrm{R}$ \\
\hline & Degree of truth & & & & -2.711853 & ${ }^{*} 0.009814114$ & s \\
\hline & $\begin{array}{l}\text { Degree of Business } \\
\text { group }\end{array}$ & & & & 3.9154652 & $\star \star 0.000342707$ & $\mathrm{~s}$ \\
\hline & Degree of $\Pi$ group & & & & -0.870024 & 0.38947875 & $\mathrm{R}$ \\
\hline \multirow{4}{*}{$\begin{array}{l}\text { Characteristi } \\
\text { cs of social } \\
\text { network }\end{array}$} & $\begin{array}{l}\text { Constraints and } \\
\text { redundancy of structural } \\
\text { holes }\end{array}$ & & & & -3.073365 & $*_{0.003801519}$ & s \\
\hline & Degree Centrality & & & & 5.0660672 & $*{ }^{2} .5899 \mathrm{E}-06$ & s \\
\hline & Closeness Centrality & & & & -4.236125 & $* 0.00012971$ & $\mathbf{s}$ \\
\hline & Betweeness Centrality & & & & -0.324164 & 0.747502598 & $\mathrm{R}$ \\
\hline \multirow{4}{*}{$\begin{array}{l}\text { Individual } \\
\text { Capacities }\end{array}$} & Degree of Personal skill & & & & -2.785062 & ${ }^{*} 0.008138508$ & $\mathrm{~s}$ \\
\hline & Degree of Authority & & & & -0.228836 & 0.820162493 & $\mathrm{R}$ \\
\hline & $\begin{array}{l}\text { Degree of awareness in } \\
\text { Business }\end{array}$ & & & & 0.3637134 & 0.717987427 & $\mathrm{R}$ \\
\hline & $\begin{array}{l}\text { Degree of awareness in } \\
\Pi\end{array}$ & & & & 1.3828787 & 0.174373686 & $R$ \\
\hline
\end{tabular}

Note $>N=53, P<.05^{*} P<.001$

\section{〈Figure 9〉 Multiple Regression Analysis}

If the hypothesis of the present research is verified according to the above analysis result, it is as follows.

First, the hypothesis of influence (H1-3) of knowledge sharing between the strong tie structure (H1-2) connected by reliability and the weak tie structure of business organizations was selected in the relationship (H1) between the tie structure and knowledge sharing of a social network. This means that the communication connected with the tie structure and reliability of traditional business structure has a positive influence on knowledge sharing.

Second, in the influence (H2) of knowledge sharing, it was verified that the structural holes and Centrality revitalize more knowledge sharing in the structure of efficient structural holes (H2-1). Also, it appeared that the higher the resources of Degree Centrality and Closeness Centrality become, much more knowledge sharing is revitalized (H2-2). It is important that the efficient structural holes is maintained by focusing on resources that the centrality of a social network is high.

Third, it appeared that the individual technical literacy ability has influence in individual ability and information technology, business recognition and knowledge sharing (H3), and the elements of information technology, and it was analyzed that the recognition of business knowledge and authority don't have a big relationship with knowledge sharing.

\section{Conclusion}

The recognition on influence of structure and characteristics of a social network of knowledge sharing is being recognized as an important method for activation of knowledge sharing. The purpose of present 
research is to analyze a knowledge network inside an organization growing like an organism through self-organization and to utilize it as basic material for knowledge sharing.

The research has analyzed the influence factors of knowledge network of knowledge sharing and expectation effects.

First, social network indexes of knowledge network of knowledge sharing were developed.

Second, the influence factors were analyzed by analyzing the structure and characteristics of knowledge network of knowledge sharing. Third, these research results will be a foundation of knowledge network analysis of knowledge management in the future.

As shown in network analysis and statistics result, it was analyzed that the weak connection structure of trust, efficient network structure and centrality of a network are important factors of knowledge management.

If the research results are arranged, it is as follows.

1. The knowledge sharing was more activated in the strong tie structure bound with reliability. Various works and tie of trust structure of communication in a project unit are important.

2. The knowledge sharing was more activated in the structure of structural holes with duplication and limitation of network structure. It can be understood that although the tie ring that knowledge is shared is smaller, it is well circulated in network structure composed of tie of an effective hub. It is important to redesign it with structure of an efficient network and systematically design the hub of important structural hole's position.

3. It can be understood that the centrality has very important influence on knowledge sharing. The node gathered in the central structure of a network plays a role of a connector that holds the core knowledge of knowledge sharing and connects it. In order to observe the node becoming the center inside an organization and achieve a goal of the organization, it should be considered who plays a role at the central structure and should play for knowledge sharing.

4. It can be understood that the influence of knowledge sharing is different according to holding of individual ability. The individual ability for various knowledge sharing, namely, the individual ability such as understanding of the present information and knowledge environment, and utilization, etc. of information literacy-related tools have much influence on knowledge sharing.

The ability that solves problems by better utilizing and sharing knowledge became an important part in understanding of knowledge-related network structure and properties. The understanding on various social networks can analyze the weak and strong points about the tie of knowledge, so the knowledge sharing can be successfully drawn by analyzing and changing the network. 


\section{References}

Allee, V. 1997. The Knowledge Evolution: Expanding

Organizational Intelligence. ButterworthHeinemann.

Burt, R. S. 2002. "The social capital of structural holes.” In M. F. Guillén The New Economic Sociology: Developments in an Emerging Field. New York: Russell Sage Foundation. 148-190.

Ciborra, C. and G. Patriota. 1998. "Groupware and teamwork in RandD: Limits to learning and innovation." RandD Management, 28(1).

Coleman, D. 1999. Groupware: Collaboration and Knowledge Sharing. Knowledge Management Handbook. CRC Press, Boca Raton, FL.

Davenport, T. H. and L. Prusak. 1998. Working Knowledge: How Organizations Manage What They Know. Harvard Business School Pr.

Drucker, P. F. 1993. Managing for the Future. Butterworth-Heinemann Oxford, England.

Freeman, Linton C. 1977. "A set of measures of centrality based on betweenness." Sociometry, 40: 35-40(1).

Granovetter, M. S. 1973. "The strength of weak ties." AJS, 78(6).

Khamseh, H. M. and D. R. Jolly. 2008. "Knowledge transfer in alliances: Determinant factors." Journal of Knowledge Management, 12(1): 37.

Krackhardt, D. 1992. "The strength of strong ties: The importance of philos in organizations." In Nohria N. and R. Eccles (Eds.) Networks and Organizations: Structure, Form, and Action. Boston, Mass.: Harvard Business School Press. 216-239.

Kim, Gu. 2003. "Exploratory study on motivation of knowledge sharing utilizing information \& Communication technology." Journal of Korean Association Regional Information, 6(1): 69-01.

O’Dell, C. and C. J. Grayson. 1998. "If only we knew what we know." California Management Review, 40(3): 154-174.

Podolny, J. M. and J. N. Baron. 1997. "Relationships and resources: Social networks and mobility in the workplace." American Sociological Review, 62(5): 673-693.

Ronald, B. 1992. Structural Holes: The Social Structure of Competition." Cambridge: Harvard.

Roos, G. and J. Roos. 1997. "Measuring your company's intellectual performance." Long Range Planning, 30(3): 413-426.

RUGGLES, R. 1998. "The state of notion: Knowledge in practice." California Management Review, 40(3): 80-89.

Scott, D. W. 1992. Multivariate Density Estimation: Theory, Practice, and Visualization. WileyInterscience.

Simonin, B. L. 1999. "Ambiguity and the process of knowledge transfer in strategic alliances." Strategic Management Journal, 20(7): 595-623. Skyrme, D. J. 2002. "Developing a knowledge strategy: 
74 Journal of the Korean Society for Information Management, 27(2), 2010

From management to leadership knowledge."

In Daryl Morey, Mark Maybury, and Bhavani

Thuraisingham (Eds.). Knowledge Manage-

ment: Classic and Contemporary Works.

Cambridge, Mass: MIT Press. 61-84.
Wiig, K. M. 2000. Application of Knowledge Management in Public Administration. [cited 2010. 6.4].

$<\mathrm{http}$ //www.krii.com/downloads/km_in_pu blic_admin_rev.pdf> 